\title{
Research on the Scope of the Government Information in China
}

\author{
Chen Mingtsung ${ }^{1 *}$, Zhong Hongsen ${ }^{2}$ \\ ${ }^{1}$ Department of Public Administration, Nan fang College of Sun Yat-sen University, Guangzhou, Guangdong, \\ 510000, China \\ ${ }^{2}$ Department of Public Administration, Nan fang College of Sun Yat-sen University, Guangzhou, Guangdong, \\ 510000, China \\ *Corresponding author's e-mail: 306470714@qq.com
}

\begin{abstract}
The government's information publicity not only depends on the government's idea of publicity and citizens' awareness of knowledge, but also depends on the mutual cooperation of relevant legal systems. The amendment of the law of the people's Republic of China on the protection of state secrets is only a part of the further improvement of the legal system related to information disclosure. Only with the help of more open and clear system norms can truly achieve a reasonable balance between citizens' right to know and the protection of state secrets. The democratic vision of "information openness", "administrative transparency" and "informed supervision" described in the "Regulations on the disclosure of government information" can truly become a reality. How to make the law of keeping state secrets more scientific, more humane and more in line with the spirit of the rule of law is the basic problem of the scope of the government information not open.
\end{abstract}

Keywords: government information, information disclosure, state secrets, review mechanism, administration according to law

\section{PREFACE}

Over the past 40 years of reform and opening up, China has made remarkable achievements in economic development and improving people's living standards. However, compared with the rapid development of the economy, the transformation of the government and its administrative functions are relatively lagging behind, and the openness of administrative information, especially the openness of administrative information, is still a big problem for the main body of the market economy. At present, only a small part of the information held by the government and its working departments is actually open to the public, and the vast majority is something that ordinary people can't access. However, an efficient government should be one that can be open to citizens. Therefore, how to improve the open mechanism of government affairs and the enthusiasm of citizens to participate in political life are the problems that our government should face to.

The regulations on the publicity of government information came into effect on May 1, 2008. It has been 12 years since then. There are not only information publicity models such as the Wenchuan earthquake, but also citizen actions that have been frustrated in applying for the publicity of government information. The reality of openness or not reflects the differences in administrative concepts of different government departments. The basic legislative spirit of the regulations on the publicity of government information is "taking publicity as the principle and non publicity as the exception", and the "exception" is that "administrative organs shall not disclose government information involving state secrets, business secrets and personal privacy" The regulations on the disclosure of government information establishes a confidentiality review mechanism for this purpose, which requires the administrative organ to review the government information to be disclosed in accordance with relevant laws and regulations. This means that the "Regulations on the disclosure of government information" and the "law on the protection of state secrets" are closely related. In practice, whether the government information is "open" or "confidential" also needs to be answered by relevant laws and regulations.

Therefore, the amendment of the law of the people's Republic of China on the protection of state secrets will help to draw a clear line between "publicity" and "confidentiality". The reform ideas of "narrowing the scope of state secrets" and "solving the untimely declassification of state secrets" are more expected, because this new thinking of legislation, which is transforming from "emphasizing confidentiality" to "making it as public as possible", is obviously conducive to dismantling the original legal barriers to information disclosure, and curbing the behavior of "information blockade" in the name of "state secrets". 


\section{THE LEGAL THEORY BASIS OF GOVERMENT INFORMATION NON DISCLOSURE}

When an administrative organ exercises its power, which may cause adverse results to citizens, it needs to abide by a fair procedure. The establishment of information disclosure system enables citizens to predict the direction of government administration, so as to reflect or cooperate in advance to ensure the realization of their rights and interests, and eliminate the fear and suspicion of secret administration. So "openness is the premise of fairness and justice". In addition, modern law is the embodiment of the public will of the people of sovereign countries through the Legislative Council, that is to say, the recognition of modern law comes from the procedure of democratic legislation. So, it is legislation, and administrative law enforcement. The implementation of information disclosure system can be regarded as the extension of communication rationality of modern law in administrative procedure.

The right to know is a fundamental right of citizens. According to Article 35 of the constitution, "citizens of the people's Republic of China have the freedom of speech, publication, assembly, association, procession and demonstration.". The so-called "freedom of speech" actually refers to the freedom of information circulation, including, of course, the freedom of people to know information (that is, the right to know). In addition, the publicity of administrative information has not only its constitutional basis, but also its administrative law basis. The essence of administrative law is the restriction of administrative power. Its purpose is to prevent the expansion and abuse of administrative power through proper and effective administrative procedures, to ensure the rule of law and the rights and interests of the people. Based on this, the administrative subject should open the administrative information to the public, so that citizens can exercise the right to know in accordance with the procedures prescribed by law.

Of course, any country has its own confidential matters, such as military affairs, foreign affairs, national defense, public security, national security and anti-terrorism. There are some matters that need to be kept secret. Even so, not all of these things are classified. It is the jurisdiction of the judicial department to identify the legitimate confidential matters and to prevent a few people from covering up their responsibilities in public affairs on the basis of confidentiality. Therefore, it is the key to prevent the minority from infringing the civil rights and hindering the public affairs to judge what should be kept secret and what should not be kept secret by the rule of law. Citizens have the right to know, the right to supervise the government and not to conceal important information from citizens, which is the basic requirement of the rule of law.

According to the basic requirements of the law of the people's Republic of China on the protection of state secrets in the spirit of the rule of law, it must define the scope of confidentiality strictly, reasonably and clearly.
For example, normal historical and scientific research and social investigation, including civil investigation and academic discussion, which do not involve major secrets, should not belong to the scope of confidentiality. Even government records, including confidential documents, cannot be kept secret indefinitely. For example, it needs to be declassified 50 years later and made public for historians and other experts, politicians and the public to study. This paper holds that all these aspects will be clearly defined and reasonably implemented with the progress of the rule of law.

Keeping state secrets and promoting information disclosure are complementary. Government informatization is an important direction of government system reform. However, due to the relative lag of China's confidentiality system and the imperfection of the government information disclosure law, for example, the interpretation of confidentiality often has the subjective randomness of the administrative department. Such as natural disasters, major production safety accidents, important criminal cases, poisoning cases, etc., all belong to the scope of confidentiality. All of these are not state secrets in modern countries ruled by law, so they are the objects of government affairs publicity and media supervision. Because of this, it can be said that the backward confidentiality system has become a major obstacle to promote the openness of government affairs in China. How the government should open the door of "government information" and eliminate the information barrier between the government and the public as much as possible has become an important content of the study on the revision of the confidentiality law in China.

\section{THE SCOPE OF GOVERMENT INFORMATION}

At present, there are some regulations on the non-public administrative information in China, which are scattered in various laws and regulations. However, because the regulations are not centralized, specific and contradictory, it is not suitable to grasp them in practice. In my opinion, except for the matters that cannot be disclosed under the mandatory provisions of the confidentiality law, the other cases belong to the matters that can be disclosed. As for how to define the scope of non disclosure, it can regulate it from the following five aspects:

\subsection{STATE SECRETS}

Including national security interests and national economic interests. The information related to state secrets includes: (a.)secrets in major decision-making of state affairs; (b) secrets in national defense construction and armed forces activities; (c.)secrets in diplomatic and foreign affairs activities; (d.)secrets in national economic and social development; (e.)secrets in science and technology; and f. maintenance of state security activities 
The secret. The above six types of information are strictly closed to the public. In addition, the chapter of the crime of endangering national security in the criminal law stipulates: stealing, spying, buying, illegally providing state secrets or intelligence for overseas institutions, organizations and personnel Here, "state secret" and "intelligence" are two words juxtaposed in logical relationship, so this "intelligence" belongs to the category of national security undoubtedly. Therefore, in addition to the national security information that is not open to the public, it is also stipulated in our country not to disclose the information related to national security to "overseas institutions and organizations" except for "state secrets".

\subsection{PERSONAL PRIVACY}

The so-called right of privacy refers to the individual's unwillingness to be known by the outside world, and the public result will bring adverse personal records. For example, disciplinary action, criminal record, medical condition, etc. The administrative information that constitutes personal privacy is all the files that record personal information. However, not all the personal information recorded by administrative organs can constitute personal privacy. In some cases, it is a personal record of privacy for some people, but not for others. The administrative organ only refuses to disclose the information that constitutes personal privacy. However, the information about personal privacy is not completely closed to the public, and the administrative organ can refuse to open it only under certain conditions and to a certain extent. First, individuals have the right to apply to the government to make their personal files public. Second, an individual may apply to consult the archives of others, and the administrative organ shall decide whether to make them public. In a word, compared with other interests, such as national interests and public interests, the nature of personal privacy is certainly inferior, but different interests can not be easily compared in a quantitative way.

\subsection{BUSINESS INTERESTS}

Some information held by the government may be unique to the counterpart of the administrative act, while others do not know it. Such information is often of great economic value to the owner, so the owner will protect this information from outsiders. In the field of business information, this is business secret. Documents containing such information publicly will make others use the information owned by the original owner, then the original owner will lose its dominant position in the market competition, and its interests will be damaged. To open such information is not conducive to the competition between enterprises and give full play to their respective expertise and innovation spirit. Of course, the value of trade secrets is not absolute. When there are various conflicts of interest, the trade interests can only go to the back row, and the national interests and public interests must take priority. The protection of trade secrets is similar to the protection of personal privacy, but the scope and strength of protection are smaller than personal privacy.

\subsection{PUBLIC INTEREST}

According to the principle of public interest, government departments shall not disclose to the public any information that may damage the safety and interests of the public. These information include: those that may hinder the law enforcement procedures; those that may deprive a fair trial or a fair ruling; those that have secret information sources or secret information; those that disclose the techniques and procedures of investigation; and those that endanger the safety of law enforcement personnel. Once the information listed above is made public, it may cause huge losses to the safety and interests of the public. Therefore, under certain conditions, the information can not be made public according to law.

\subsection{ADMINISTRATIVE EFFICIENCY}

Administrative openness and administrative efficiency have been a pair of contradictions for a long time. Only paying attention to efficiency but not to procedure will make administrative behavior not be regulated by any administrative procedure, which will lead to administrative behavior directly linked to subjective factors such as personal preference and familiarity with administrative affairs of the actor, and the actor will lose its objective impartiality; once administrative procedure is pursued in an extreme way and administrative efficiency is put aside, administrative cost will be excluded from consideration beyond the scope, the result must be tedious procedures, overstaffed institutions, overstaffed people and numerous departments. Although administrative transparency is the fundamental attribute of administrative procedure and the basic requirement of administrative rule of law, it is an absolute principle, but in some cases, in order to take into account the administrative efficiency, the disclosure of some administrative information will only increase the cost of the administrative organ, and will not benefit anyone, or will cause trouble for the administrative organ to perform its official duties, it is considered that it will not damage the interests of the public In this case, such information can be exempt from disclosure.

In a word, publicity is inevitable. As long as all administrative information is not destroyed, it can be obtained by the public; and non publicity is temporary. Once the reasons for non publicity are lost, or the time limit for non publicity is exceeded, or the requester of non publicity information is a legal person who can obtain such information, the non publicity information will still 
[2] Dong Jiaqi, On the way of government information

be disclosed.

\section{CONCLUSION}

The confidential review mechanism set up in the regulations on the disclosure of government information means that the administrative organ has greater discretion on whether to disclose the information. Therefore, it is inevitable to worry about whether some government departments and officials will take the confidential review mechanism as a shield to pack a large amount of government information that should be open into the basket of "state secrets" so as to compress or even deprive it legally Citizens' right to know. Of course, in certain circumstances, the government has the right to keep "secrets". However, publicity is not the exclusive choice of administrative rule of law, that is to say, the government sometimes has the right to keep some "secrets". In some special situations, the disclosure of administrative information will cause conflicts with other important social interests, such as national security, personal privacy, etc., then the government can refuse to disclose such information that may have a negative impact on the state, society or private. In the case of such conflicts, it is more in line with social interests to restrict the disclosure of administrative information.

\section{REFERENCES}

[1] Liu Yandong, Regulation effect of government information disclosure regulations on deciding secrets, Chinese Public Administration. (02) (2020), pp. 11-12. disclosure, Legality Vision. (05) (2020), pp. 201-202.

[3] Qi Xiumei, On the Conflict of Value in the Publicity of Government Information, Journal of Hebei Youth Administrative Cadres College. 32(01) (2020), pp. 38-43.

[4] Kong Fanhua, Exception from Disclosure of Privacy in the Government Information, Administrative Law Review. (01) (2020), pp. 17-29.

[5] Yan Guizhi, Non-public information disclosure, Resources and Habitant Environment. (09) (2016), pp. 20-23.

[6] Yang Weidong, New Development of Government Information Disclosure System in China, Justice of China. (09) (2019), pp. 20-24.

[7] Lin Shuang, Zhang Jie, On Government Information Disclosure and Its Perfection, Theory Research. (08) (2019), pp. 42-43.

[8] Zhang Jingdan, Chen Xi, Problems and Solutions of Government Information Disclosure in China, Legal System and Society. (06) (2019), pp. 130-131.

[9] Peng Yan, Constitutional logic of government information disclosure system in China, Law Science. (02) (2019), pp. 94-106. 